\title{
HEALTH RELATED QUALITY OF LIFE OF PATIENTS WITH SICKLE CELL DISEASE AGED 8-17 YEARS AT KAMUZU CENTRAL HOSPITAL, MALAWI
}

\author{
Stella Wachepa ${ }^{1}$, Ruth Bvalani ${ }^{2}$, Atupele Mpasa ${ }^{1}$, Shamim Namugerwa ${ }^{1}$, Teddy \\ Namubiru$^{1}$, Gloria Kaudha ${ }^{1}$, Deogratias Munube ${ }^{1}$, Joseph Rujumba ${ }^{1}$, Nmazuo Ozuah ${ }^{3}$, \\ and Sarah Kiguli ${ }^{1}$ \\ ${ }^{1}$ Makerere University College of Health Sciences \\ ${ }^{2}$ Kamuzu Central Hospital \\ ${ }^{3}$ Texas Children's Hospital
}

February 14, 2022

\begin{abstract}
Background: Sickle cell disease (SCD) is characterized by both acute and chronic complications that affect the daily lives of patients and lower their quality of life. Objective: To describe the health-related quality of life (HRQoL) and the associated factors in children aged 8 to 17 with SCD attending the paediatric haematology clinic at Kamuzu Central Hospital (KCH) in Lilongwe, Malawi. Methods: A mixed methods cross sectional study was conducted at KCH. Patient data was collected with the aid of a standardized case report form. HRQoL was assessed using PedsQL Sickle Cell Disease Module by child's report. Associations between HRQoL scores and independent variables were evaluated by a linear regression model. In-depth interviews were then carried out and the qualitative data was analyzed using content thematic analysis. Results: A hundred and sixty-three children with SCD were enrolled, $52.1 \%$ were females. Their median age was $11.2 \pm 2.7$ years. The mean global HRQoL score of the children was $62 \pm 17.3$. The highest scores were in the treatment domain $(72.5 \pm 15.1)$ while the lowest scores were in the emotions domain (55.2 \pm 28.7$)$. The mean pain score was $58.8 \pm 16.3$. The factors associated with low HRQoL scores were pain ( $\beta$-coefficient -6.97 CI $(-3.07,-15.58)$; p value 0.034$)$ and low haemoglobin levels ( $\beta$-coefficient 2.29 CI (0.65-3.91); p value 0.006 ). Conclusion: The HRQoL of this population is low. Pain and low hemoglobin were significantly associated with low HRQoL scores. A biopsychosocial model of heath care delivery and health campaigns are recommended to improve the HRQoL of the children.
\end{abstract}

\section{Hosted file}

Manuscript_Stella Wachepa for PBC.doc available at https://authorea.com/users/460475/ articles/556469-health-related-quality-of-life-of-patients-with-sickle-cell-diseaseaged-8-17-years-at-kamuzu-central-hospital-malawi 